\title{
Techno-economic feasibility analysis of a 3-kW PV system installation in Nepal
}

\author{
Ramhari Poudyal ${ }^{*}$, Pavel Loskot ${ }^{2}$ and Ranjan Parajuli ${ }^{3}$
}

\begin{abstract}
This study investigates the techno-economic feasibility of installing a 3-kilowatt-peak (kWp) photovoltaic (PV) system in Kathmandu, Nepal. The study also analyses the importance of scaling up the share of solar energy to contribute to the country's overall energy generation mix. The technical viability of the designed PV system is assessed using PVsyst and Meteonorm simulation software. The performance indicators adopted in our study are the electric energy output, performance ratio, and the economic returns including the levelised cost and the net present value of energy production. The key parameters used in simulations are site-specific meteorological data, solar irradiance, PV capacity factor, and the price of electricity. The achieved PV system efficiency and the performance ratio are $17 \%$ and $84 \%$, respectively. The demand-supply gap has been estimated assuming the load profile of a typical household in Kathmandu under the enhanced use of electric appliances. Our results show that the 3-kWp PV system can generate $100 \%$ of electricity consumed by a typical residential household in Kathmandu. The calculated levelised cost of energy for the PV system considered is $0.06 \$ / \mathrm{kWh}$, and the corresponding rate of investment is $87 \%$. The payback period is estimated to be 8.6 years. The installation of the designed solar PV system could save 10.33 tons of $\mathrm{CO}_{2}$ emission over its lifetime. Overall, the PV systems with $3 \mathrm{kWp}$ capacity appear to be a viable solution to secure a sufficient amount of electricity for most households in Kathmandu city.
\end{abstract}

\section{Highlights}

The proposed PV system achieves the levelised cost of energy by $0.06 \$ / \mathrm{kWh}$, and its investment rate is $87 \%$.

The efficiency of the proposed PV system is $17 \%$, and its performance ratio is $84 \%$.

The payback period for the deployment of the proposed PV system is 8.6 years.

Deployment of the proposed PV system can save 10.33 tons of $\mathrm{CO}_{2}$ emission over its lifetime.

\section{Introduction}

The total primary energy consumption (TPEC) of Nepal in the year 2018 was 0.17 quadrillion Btu. It is increased from 0.05 quadrillion BTU in 1999 to 0.17 quadrillion BTU in 2018, growing at the average annual rate of 7.3\% (World Data Atlas, 2018). On the TPEC, the share of biomass energy sources was $74 \%$, followed by fossil fuel

\footnotetext{
*Correspondence: rhpoudyal@gmail.com; 847043@swansea.ac.uk

${ }^{1}$ Swansea University, Fabian Way, Crymlyn Burrows, Skewen,

Swansea SA1 8EN, UK

Full list of author information is available at the end of the article
}

$17.32 \%$, coal $5.96 \%$, hydropower $3 \%$, and less than $1 \%$ was from other renewable sources (USEI Administration, 2019). The current status of energy consumption reveals that the residential sector has the highest share $(80 \%)$, followed by the industrial sector $(8 \%)$ and the transportation sector (7\%), respectively (Ministry of Finance, 2017).

By the end of the fiscal year (FY) 2018/2019, the hydroelectricity's installed capacity was 1129 MW (IHA, 2020). In the year 2020, the peak demand for electricity was around $1320 \mathrm{MW}$ (Nepal Electricity Authority, 2020). Hence, to maintain the demand, additional power is imported from India. Moreover, hydroelectricity is 
in short supply compared to the electricity market that prevailed in recent years. In FY 2017/2018, about 33\% of the total imports were accounted for petroleum products (Nepal Rastra Bank, 2018). Since there exists a massive dependency on fossil fuels, the country is spending nearly 300 billion Nepalese Rupees (1 US $\$=117.47$ NRs, January 10, 2021) on petroleum products and electricity. Nepal's total trade deficit amounted to around 11.24 billion US\$ (Statista, 2019).

The per capita electricity consumption of Nepal in FY 2018/19 was $245 \mathrm{kWh}$. The Government of Nepal has set a target to achieve per capita electricity consumption of $700 \mathrm{kWh}$ by $2021 / 22$ and $1500 \mathrm{kWh}$ by $2026 / 27$ (Nepal Electricity Authority, 2020). The higher per capita electricity consumption is assumed to follow the Government's ambition to have an $8.5 \%$ economic growth rate, making the country in the list of middle-income countries by 2030 (NRB, 2019). To deliver such a higher economic growth rate, Nepal needs to increase its electricity consumption (Parajuli et al., 2014). Due to the insufficient supply of electricity and low income, most households who even have access to electricity often consumed for lighting purposes only. Nepal's power sector is bearing an acute shortage of energy, which is primarily exacerbated by energy losses between the prime mover and the consumers' doorsteps. Integration of Renewable Energy Technologies (RETs) at the household level, e.g., through the installation of a rooftop solar photovoltaic (SPV) system, can allow the homeowners to meet their energy need independently (Poudyal et al., 2020). It can also help in the management of energy flows in the national grid and can support to reduce carbon dioxide $\left(\mathrm{CO}_{2}\right)$ emissions. The role of RETs is also argued for enhancing economic activities in developing countries like Nepal. The importance of the decentralised form of energy enterprise, such as Solar Power Company (SPC), is also inherited to cope with the country's inability to transfer electricity in poorly established distribution systems.

Nepal's transmission network is limited, outdated, and there is no position to accommodate large power generation that the Government intends to accomplish in the next 10 years (Bajracharya, 2019). Inefficient infrastructure creates substantial electricity losses due to leakage and lack of adequate transmission infrastructure (Basnett, 2014). Therefore, the stand-alone PV generation systems in the country can lessen pressure on the transmission and distribution system and reduce power losses (Bajracharya, 2019). The Government of Nepal (GoN) has set a goal to increase the share of renewable energy from less than $1 \%$ to $10 \%$ and further improve access to electricity from alternative sources, from 10 to $30 \%$ within the next 20 years. According to the energy progress report 2019, 1.3 million people have no access to electricity, and Nepal has targeted to achieve $100 \%$ electricity for all by the year 2023 (Nepal Electricity Authority, 2020. Hence the PV system would be the game-changer and help to achieve such targets (see Fig. 1).

In Nepal, a grid-connected solar system is in its emerging phase. The history of solar power has begun with the 1 -MW design at Singha Durbar, $680 \mathrm{~kW}$ system at Sundharighat, $100 \mathrm{~kW}$ system at Kharipati, $65 \mathrm{~kW}$ at Nepal Telecom, a $1 \mathrm{KW}$ test project at the Institute of Engineering, Pulchowk, Campus. However, the PV system is yet to gain momentum at a business scale (Bajracharya, 2019). Recently, a 7-MW Grid-connected PV system was added to the national grid of Nepal. Similarly, other initiatives include installing solar power in one of Nepal's regional airports (Bhairahawa airport). The estimated cost for installing the PV system in the airport mentioned above was $\$ 10$ million (i.e. 1 mil. $\$$ per megawatts) (Kathmandu Post, 2020). In 2018, the GoN initiated to formulate the required policies for net metering and feed-in tariff (FIT) (with NRs 7.30 per unit), however, reluctance to implement such policies is causing a delay in large-scale adoption (Bajracharya, 2019). Nepal Electricity Authority (NEA) has issued licenses to various PV installers to produce more than 500 megawatts of solar energy. NEA plans to have an energy mix, constituting $85 \%$ from hydropower and $15 \%$ from solar power. Nepal has abundant availability of solar energy throughout the year (Fig. 2). With the average solar radiation varies 3.6$6.2 \mathrm{kWh} / \mathrm{m}^{2} /$ day and 300 days of sunny weather, Nepal is an ideal country for harnessing solar energy (Awasthi \& Poudyal, 2018). Even so, the country's power system is mostly dominated by large hydropower. Given the nature of hydropower, mostly dominant by run-off the river types and the connected unreliable power supply during the dry season, it is imperative to upscale other renewable energy technologies, such as solar PV in the country's energy mix (Poudyal, 2019, 2020; Poudyal et al., 2019a, b, 2020).

A PV system's technological feasibility analysis is studied for different countries (Astriani et al., 2019; Al Garni \& Awasthi, 2017; Bhattacharjee \& Dey, 2014; Bhattacharyya, 2013; Cassard et al., 2011; Ghasemi et al., 2013; Haghighat Mamaghani et al., 2016; Jäger-Waldau, 2020; Jäger-Waldau et al., 2011; Kazem et al., 2017; Llamas \& Adana, 2019; Parajuli et al., 2012; Pillai et al., 2016; Shahzad et al., 2017). Regarding the use of PV energy simulation tools, a stand-alone PV system installed in Malaysia (Irwan et al., 2015) evaluated the technoeconomic performance using the "PVsyst" software 
Identification of the location and natural resources

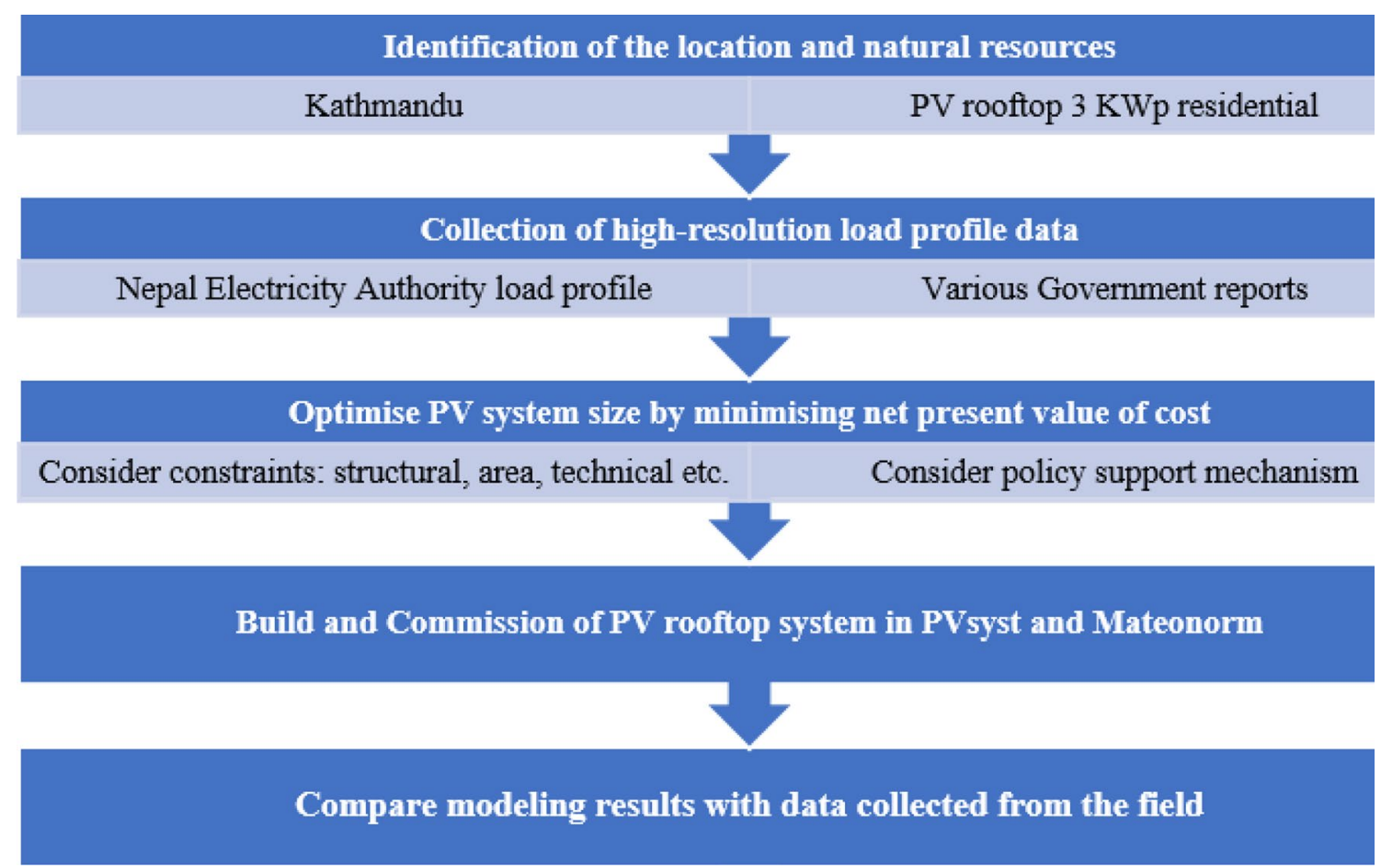

Fig. 1 A flowchart summarising our techno-economic evaluation methodology

simulation tool. PVsyst is generally used for predicting energy output instead of evaluating real-time operating data. Likewise, the performance of a stand-alone PV system is also found for Saudi Arabia (Rehman \& El-Amin, 2012). A comparative study of the grid-tied PV system in Kathmandu and Berlin are also available (Karki et al., 2012), which suggested that the solar radiation and sunshine hours of Kathmandu is better than Berlin's.

The increasing global energy demand is mostly driven by consumption in emerging economies, such as China and India. These two countries already account for half of the world's demand increases, and their consumption is expected to double by 2030. China announced that it would spend USD 363 billion on expanding its renewable energy capacity by 2020 (Poudyal, 2019). The subsidies for the new solar PV panels in China are predicted to drop by $75 \%$ in 2025 , while solar projects in India will be competitive without any financial support well before 2030. Furthermore, the Paris Agreement provides key opportunities for countries to report their fossil fuel production and their plans and strategies to align future production with climate goals, including through the global stocktake, nationally determined contributions (NDCs), long-term low greenhouse gas emission development strategies and financing (UNEP, 2019). Nepal is also one of the signatory countries of this global agreement, and it has prepared to go carbon neutral by 2050 . Under such circumstances, it is relevant that large-scale renewable energy interventions, including solar, are deployed. For an upscaled solar PV installations scenario, detailed techno-economic and policy instruments are essential. However, yet to the best of the author's knowledge, the feasibility study of photovoltaic systems in Nepalese context is very limitedly captured. Besides, analytical work and empirical evidence on solar PV system topics' socioeconomic benefits remain relatively limited (IRENA, 2014). Most importantly, the application of the available solar energy simulation models is minimal, and most of the models are site-specific and did not apply the technoeconomic viability assessments in detail. Therefore, this study aims to fill the research gaps by providing a technoeconomic appraisal of a stand-alone and grid-connected system to supply electricity for a residential home in Kathmandu, Nepal. As a case study, the location considered for the analysis is Bishalnagar, located in Kathmandu valley. This study will fill the gaps in the current literature by analysing up-to-date data in the form of clearness index, tilting angle, meteo data, relative sunshine period, effects of temperatures, and irradiations, which are critical parameters for solar PV output. 


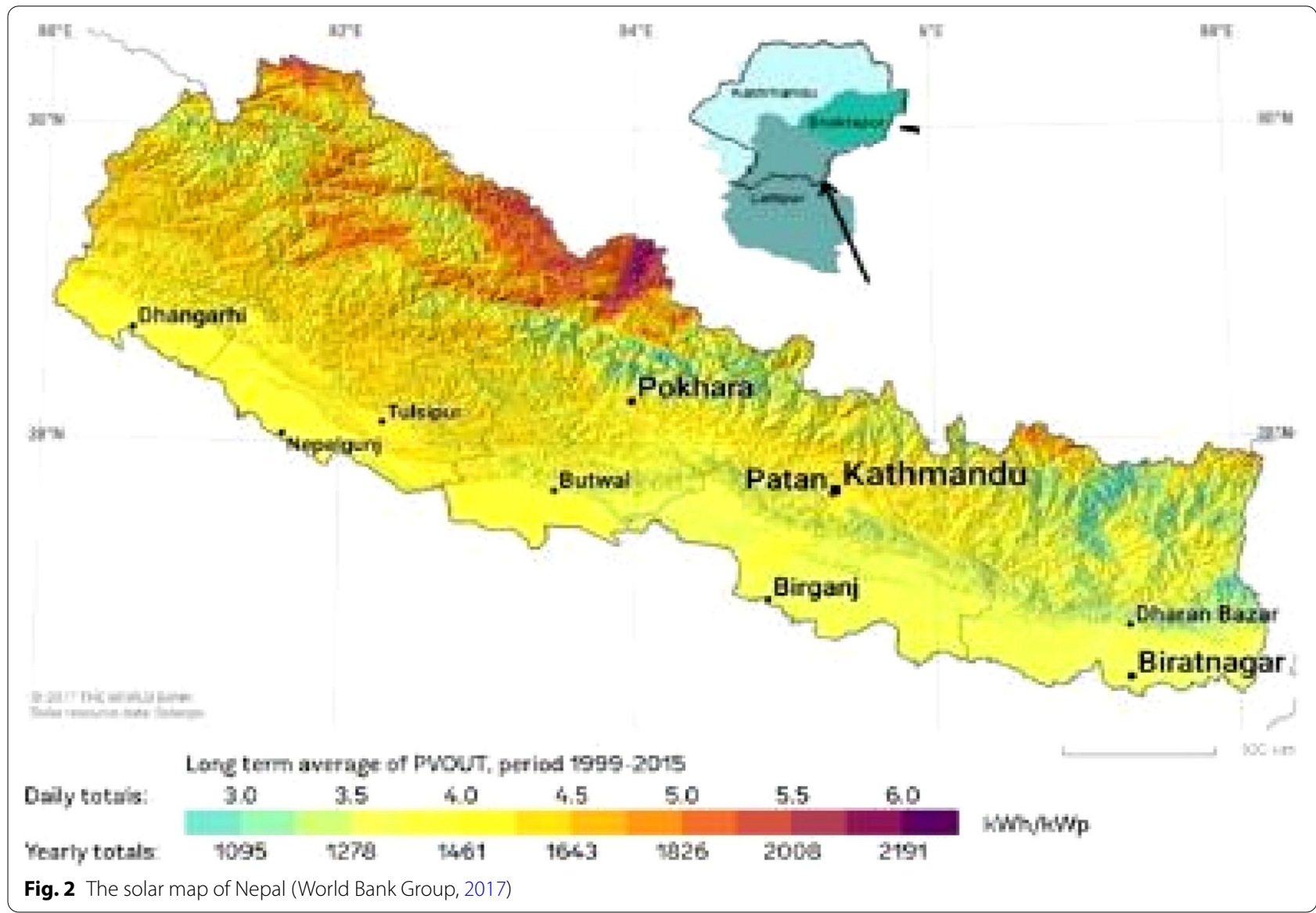

\section{Materials and methods}

\section{Simulation and optimisation software}

The simulation constituted to design a 3-kWp PV system, calculated based on the load profile of the selected study area (Table 3). For this, a PVsyst was used to analyse technical and economic analysis. PVsyst software (Ashok et al., 2020) is a tool that lets its user to analyse different configurations accurately and to evaluate the results while identifying the best feasible solution. PVsyst allows for importing files provided by the Meteonorm software so that well-measured interpolated values can be taken graphically. PVsyst deals only with gridconnected, stand-alone, pumping, and DC-grid (public transportation) PV systems (Irwan et al., 2015). The modelling details are discussed in Sect. "Model inputs and assumptions".

\section{Model inputs and assumptions}

Various inputs have been used to operationalise the Solar PV model received from an SPC supplier for a stand-alone PV system and grid-connected PV system (Tables 1, 2). For both systems, a 330-W monocrystalline panel was assumed.
Table 1 Description of a stand-alone solar power supply system SP $3 \mathrm{~kW}$

\begin{tabular}{llll}
\hline Product & Quantity & Unit price & Total price \\
\hline 330w monocrystalline panel & $10 \mathrm{pcs}$ & $\$ 92.4$ & $\$ 924$ \\
H4T PV combiner & $1 \mathrm{pc}$ & $\$ 117$ & $\$ 117$ \\
48V 60A charge controller & $1 \mathrm{pc}$ & $\$ 98$ & $\$ 98$ \\
NW3000W solar inverter & $1 \mathrm{pc}$ & $\$ 207$ & $\$ 207$ \\
200AH gel battery & $4 \mathrm{pcs}$ & $\$ 200$ & $\$ 800$ \\
Solar panel bracket & 1 set & $\$ 450$ & $\$ 450$ \\
PV cable + battery cable & 1 set & $\$ 185$ & $\$ 185$ \\
Total & & & $\$ 2841$ \\
\hline
\end{tabular}

Table 2 Description of an on-grid solar power supply system SPB 3KW

\begin{tabular}{llll}
\hline Product & Quantity & Unit price & Total price \\
\hline 330 w monocrystalline panel & 10 pcs & $\$ 92.4$ & $\$ 924$ \\
HBF 3 kW on-grid inverter & 1 pc & $\$ 340$ & $\$ 340$ \\
PV cable + battery cable & 1 set & $\$ 125$ & $\$ 125$ \\
Total & & & $\$ 1789$
\end{tabular}


Table 3 The load profile of a typical household in Kathmandu

\begin{tabular}{|c|c|c|c|c|}
\hline Appliance/loads & $\begin{array}{l}\text { Power (watts) } \\
\text { (A) }\end{array}$ & $\begin{array}{l}\text { Hours used in a day } \\
\text { (B) }\end{array}$ & $\begin{array}{l}\text { Days per week } \\
\text { (C) }\end{array}$ & $\begin{array}{l}\text { Watt-hours per week } \\
\text { (A) } \times(B) \times(C)\end{array}$ \\
\hline Lamp LED & 15 & 7 & 7 & 735 \\
\hline TV & 80 & 5 & 7 & 2800 \\
\hline Laptop & 50 & 5 & 7 & 17,500 \\
\hline Computer & 80 & 5 & 7 & 2800 \\
\hline Fridge & 58 & 24 & 7 & 9744 \\
\hline Fan & 150 & 2 & 7 & 2100 \\
\hline Rice cooker & 1000 & 1 & 7 & 7000 \\
\hline Washing M/C & 1000 & 1 & 2 & 2000 \\
\hline Microwave & 1000 & 1 & 7 & 7000 \\
\hline Iron & 1000 & 0.5 & 5 & 2500 \\
\hline Dryer & 1000 & 1 & 5 & 5000 \\
\hline Kettle & 1200 & 0.75 & 7 & 6300 \\
\hline Well pump & 750 & 1 & 4 & 3000 \\
\hline Smartphone Recharge & 6 & 3 & 7 & 126 \\
\hline Vacuum & 1000 & 1 & 2 & 2000 \\
\hline \multirow[t]{2}{*}{ Other } & 120 & 1 & 7 & 840 \\
\hline & $\begin{array}{l}\text { Highest power used at one } \\
\text { time }\end{array}$ & & Total power per week & $55,695 \mathrm{Wh} / \mathrm{w}$ \\
\hline
\end{tabular}

Table 4 The module specification of the proposed PV system for Kathmandu

\begin{tabular}{ll}
\hline Model & Talesun-TP672M -330 \\
\hline Manufacturer & \\
Electrical characteristics & \\
Maximum power (Pmax) & $330 \mathrm{~W}$ \\
Maximum power voltage (Vmp) & $37.3 \mathrm{~V}$ \\
Maximum power current (Imp) & $8.85 \mathrm{~A}$ \\
Short-circuit current (Isc) & $9.19 \mathrm{~A}$ \\
Open-circuit voltage (Voc) & $46.1 \mathrm{~V}$ \\
Module efficiency & $17 \%$ \\
Cell size and series & Monocrystalline \\
& $156 \times 156-72 \mathrm{pcs}$ \\
Temperature coefficient of Pmax & $(6 \times 12)$ \\
Temperature coefficient of Voc & $-0.41 \% /{ }^{\circ} \mathrm{C}$ \\
Temperature coefficient of Isc & $-0.31 \% /{ }^{\circ} \mathrm{C}$ \\
Mechanical characteristics & $+0.055 \% /{ }^{\circ} \mathrm{C}$ \\
Model dimension & \\
Frame & $1960 \times 992 \times 35 \mathrm{~mm}$ \\
& Anodized aluminium \\
Glass & alloy \\
Junction box and cable & $3.2 \mathrm{~mm}$, High transmis- \\
Weight & sion, tempered glass \\
\hline
\end{tabular}

A value-added tax (VAT) rate of $15 \%$ is added to the original quotation, and shipping cost of $\$ 405$ for a total volume of $1.2 \mathrm{~m}^{3}$ and $360 \mathrm{~kg}$ is added to the grid-connected system and shipping cost of $\$ 479$ for the total volume of $1.96 \mathrm{~m}^{3}$ and $537 \mathrm{~kg}$ is added to the stand-alone system. The operation and maintenance $(\mathrm{O} \& M)$ cost was assumed at $3 \%$ of the capital cost. The O\&M cost is assumed to increase by $5 \%$ per year. The annual rate for the cost of insurance for the plant was set at $1 \%$ of the capital cost. The output is assumed to de-rate $1 \%$ per year, and the lifetime is taken as 25 years. The technical and commercial loss in the system is $15 \%$, and the saleable output is obtained after deducting the energy lost in the system. Any available capital grant is applied first (\$173), and the grant amount reduces the capital investment requirement. The balance of capital is assumed to be funded through loan and equity at an 80:20 ratio. Further, an inflation rate of $9.9 \%$, the interest bank rate of $2.25 \%$ for 15 years, $0.35 \%$ administration charge of the bank, and a discount rate of $0.06(6 \%)$ are considered to calculate the real rate of interest. The fixed feed-in tariff rate of $\$ 0.063 / \mathrm{kWh}$ is taken from various sources (Government of Nepal, 2013; Mainali \& Silveira, 2012; Mathew, 2007; Nepal Investment Bank Limited, 2020). The load profile calculated to estimate the number and size of panels required for a project is shown in Table 3. 


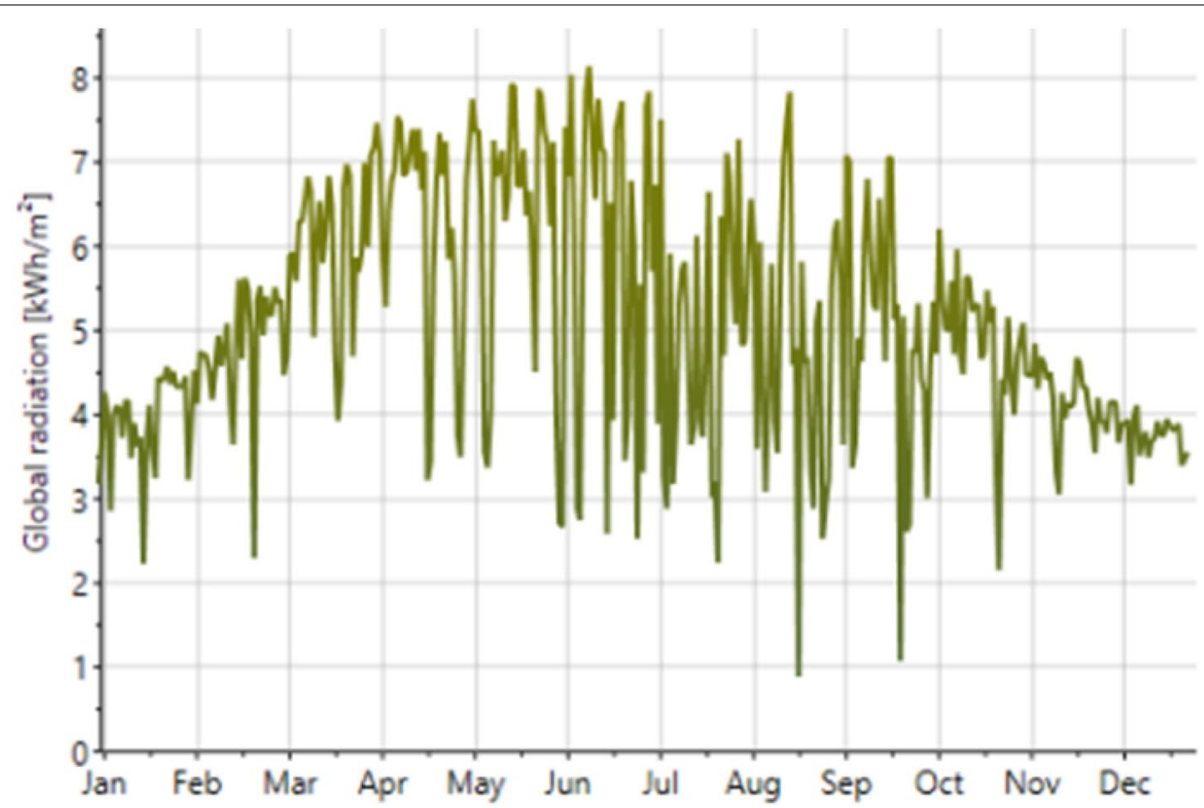

Fig. 3 Daily global radiation at the selected location in Kathmandu

\section{Solar panel specification}

The specification of the module used for analysis is listed in Table 4.

\section{Evaluation of site meteorological data}

A Meteonorm 7.3 software is used to obtain the relevant solar radiation data for the selected study area.

\section{Global irradiation}

The potential for PV power generation, as reported by Solargis, is illustrated in the solar map of Nepal (Fig. 2). The solar irradiance figure on a month-by-month basis is shown in Fig. 3, which illustrates the average daily irradiance based on mounting the solar array (see Table 5) flat on the ground.

The solar path suggests the sun's position relative to the tilt and Azimuth angle view (Fig. 4). Nepal has abundant solar energy available throughout the year (Fig. 2), with the average solar radiation varying from 3.6 to $6.2 \mathrm{kWh} /$ $\mathrm{m}^{2}$ /day with 300 days of sunny weather (Awasthi \& Poudyal, 2018; World Bank Group, 2017). Therefore, it is an ideal place for solar energy. Solar radiation in different seasons is enumerated in Table 6. Summer has the highest radiation with $24.76 \mathrm{MJ} / \mathrm{m}^{2}$, whereas winter has the lowest with $1300 \mathrm{MJ} / \mathrm{m}^{2}$, as listed in Table 6 .

Sunshine duration of Kathmandu appears encouraging for the rooftop PV module, as presented in Fig. 5. April, May, October, and November have the highest sunshine duration for more than $8 \mathrm{~h}$, which means more electricity
Table 5 The areas under different annual normal radiations in Nepal (El Gayar \& Anthony, 2010)

\begin{tabular}{lllr}
\hline S no. & $\begin{array}{l}\text { Solar radiation } \\
\text { class } \\
\left(\mathbf{k W h} / \mathbf{m}^{2} / \text { day) }\right.\end{array}$ & $\begin{array}{l}\text { Average annual } \\
\left(\mathbf{k W h} / \mathbf{m}^{2} / \text { day) }\right.\end{array}$ & $\begin{array}{l}\text { Area } \\
\left(\mathbf{k m}^{2}\right)\end{array}$ \\
\hline 1 & $3.5-4.5$ & 4.16 & 2174.49 \\
2 & $4.5-5.5$ & 5.22 & $32,587.00$ \\
3 & $5.5-5.75$ & 5.561 & 2729.53 \\
& Total & 14.941 & $37,491.02$ \\
\hline
\end{tabular}

can be generated during these months. It should be noted that Nepal's hydropower system generates half of its capacity in April and May because of their seasonal flow of the river. In the long run, Nepal can balance its energy system by utilising the Solar PV technologies during this period rather than importing electricity from India (Bajracharya, 2019).

\section{Temperature}

The temperature of Kathmandu, all round the year, ranges from 2.5 to $30{ }^{\circ} \mathrm{C}$. Figure 6 illustrates the temperature of Kathmandu all round the year. In general, high temperature decreases the PV system's efficiency, and low temperature makes power conversion in PV modules more efficient. 


\section{Solar paths at Bishalnagar, (Lat. $27.7224^{\circ} \mathrm{N}$, long. $85.3418^{\circ} \mathrm{E}$, alt. $1295 \mathrm{~m}$ ) - Legal Time}

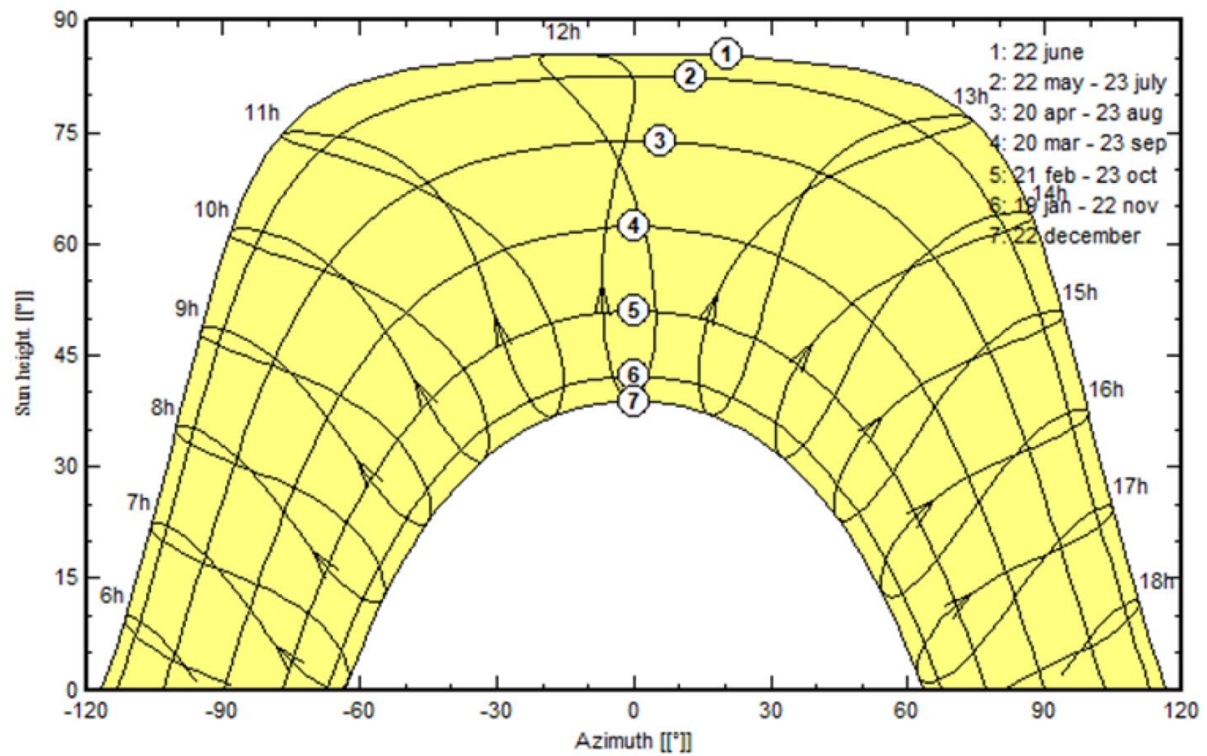

Fig. 4 The solar path of Kathmandu

\section{Humidity and wind}

The results of the effect of wind velocity on the performance of the solar system by (Fath, 1995) observed that increasing the wind speed from 0 to $8 \mathrm{~m} / \mathrm{s}$ decreases the total production by less than $10 \%$ (Blanco \& Malato, 2009). Low- and medium-speed winds, close to the ground, have cooling effects on the PV modules, increasing their conversion efficiency and increasing energy generation. However, the occurrence of stronger winds poses a risk of damaging the modules and construction components. Although Kathmandu has a constant wind speed, March has the highest wind speed of $2.3 \mathrm{~m} / \mathrm{s}$, but this speed does not affect the solar generation, in any case.

Table 6 Climatic solar radiation in Kathmandu, Nepal (Poudyal et al., 1970)

\begin{tabular}{lll}
\hline S. no. & Season & $\begin{array}{l}\text { Solar } \\
\text { radiation } \\
\mathbf{M J} / \mathbf{m}^{\mathbf{2}}\end{array}$ \\
\hline 1 & Winter & 13.00 \\
2 & Spring & 20.86 \\
3 & Summer & 24.76 \\
4 & Autumn & 15.48 \\
\hline
\end{tabular}

\section{Precipitations}

The average yearly rainfall is about 55 inches, most of which falls from June to September.

January to May and October to December have low precipitation, where June to September have high rainfall (Fig. 7). Although July has the highest rainfall, it still has $5 \mathrm{~h}$ of sunshine. The amount and periodicity of rain determine the cleaning efficiency of the surface of the PV modules. Manual cleaning of PV modules requires special attention in a dry and dusty climate. Average relative humidity in Kathmandu shows that humidity remains $80 \%$ throughout the year except for March to May, when it drops to $60-70 \%$.

\section{Results}

In PVsyst, the simulation is carried out for a $3-\mathrm{kW}$ offgrid (stand-alone) and on-grid system. The technoeconomic parameters for simulation are described in Sect. "Materials and Methods".

\section{Modelling using PVsyst software}

The PV system's feasibility analysis has been conducted with the PVsyst software for two scenarios: case 1-standalone (off-grid) system and case 2-grid-connected system. The simulation results are presented below. 


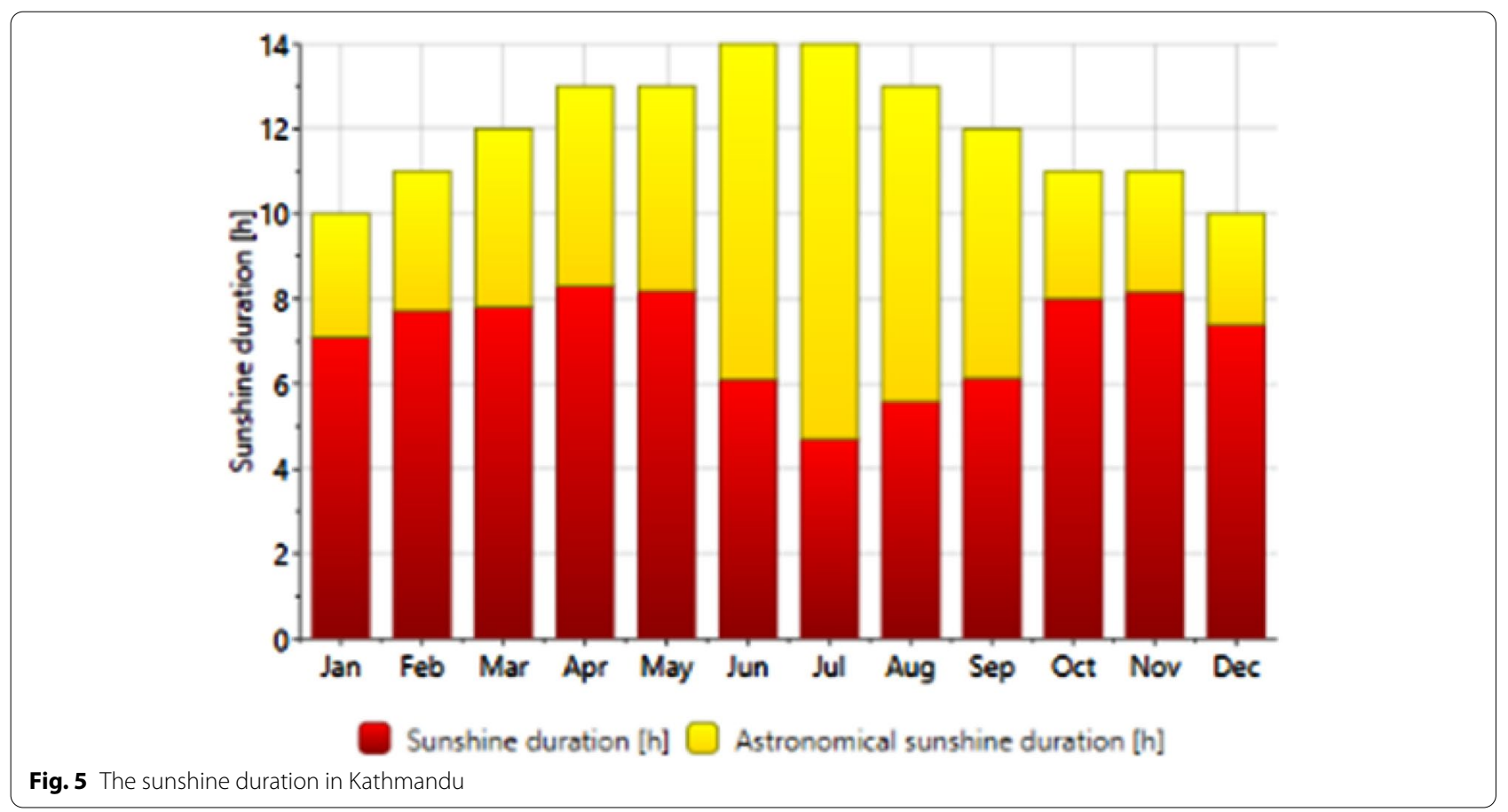

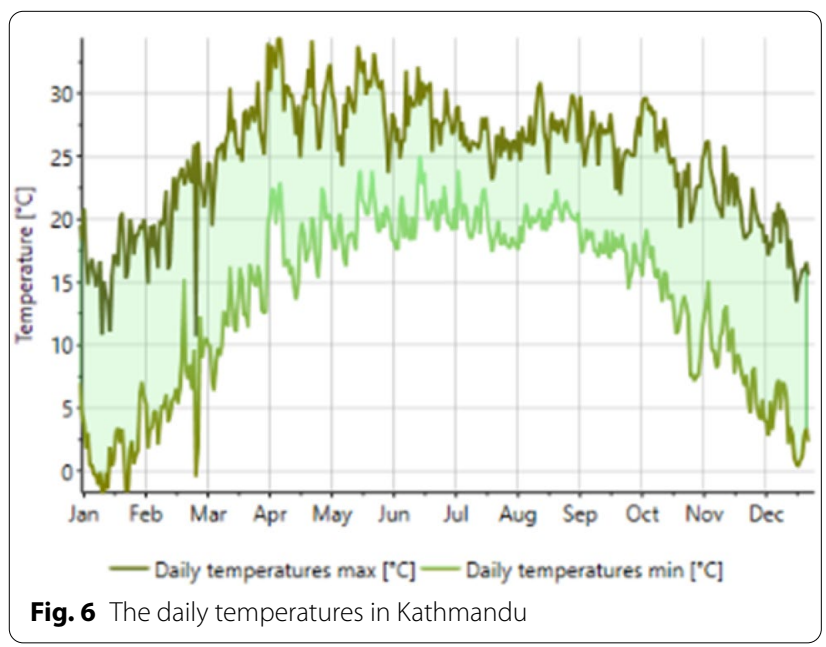

Case 1: stand-alone (off-grid) system

Energy balances and the performance of the selected PV system are shown in Table 7, which includes variables like global irradiance on the horizontal plane, effective global irradiance considering soiling losses and shading losses, DC energy available, and power unused due to full battery loss. Apart from these variables, energy missed, energy user, energy load, and solar fraction are also calculated. Each variable's values are mentioned in balances, and the main results were obtained in terms of monthly and yearly costs. In the selected study area, the annual global irradiance on the horizontal plane is $1869.2 \mathrm{kWh} /$ $\mathrm{m}^{2}$, and significant global irradiance after optical losses are $2086.9 \mathrm{kWh} / \mathrm{m}^{2}$. The yearly DC energy available from the monocrystalline PV array is $5288.2 \mathrm{kWh}$, energy unused is $1943.7 \mathrm{kWh}$, and energy missed is $43.66 \mathrm{kWh}$. The annual average solar fraction is observed to be 0.986 .

Normalised energy productions such as unused energy (battery full), collection loss, system loss and battery charging, and power supplied to the user per installed $\mathrm{kWh} / \mathrm{kWp} /$ day were based on the simulations (Fig. 8). These normalised productions are defined by the IEC norms in the photovoltaic system performance mounting guidelines for measurement, data exchange, and analysis (Commission I-IE, 1998). The parameters selected for calculating the normalised energy production with their values are also shown in Fig. 8.

The arrow loss diagram shown in Fig. 9 helps to analyse the various losses that are to be encountered while installing a PV plant. This result is the gain of $14.2 \%$ global incident in the collector plane and loss of energy, i.e. 2.3\% due to array incidence angle. After the PV conversion, the produced nominal array energy at standard testing conditions (STC) is $6208 \mathrm{kWh}$, with the PV array efficiency at $16.93 \%$. Array output power is $3518 \mathrm{kWh}$. The various losses occur in this stage: $0.4 \%$ due to irradiance level, $9.6 \%$ losses due to temperature, $1.1 \%$ due to module array mismatch, and $1.9 \%$ of the Ohmic wiring losses. Available energy on an annual basis at the 


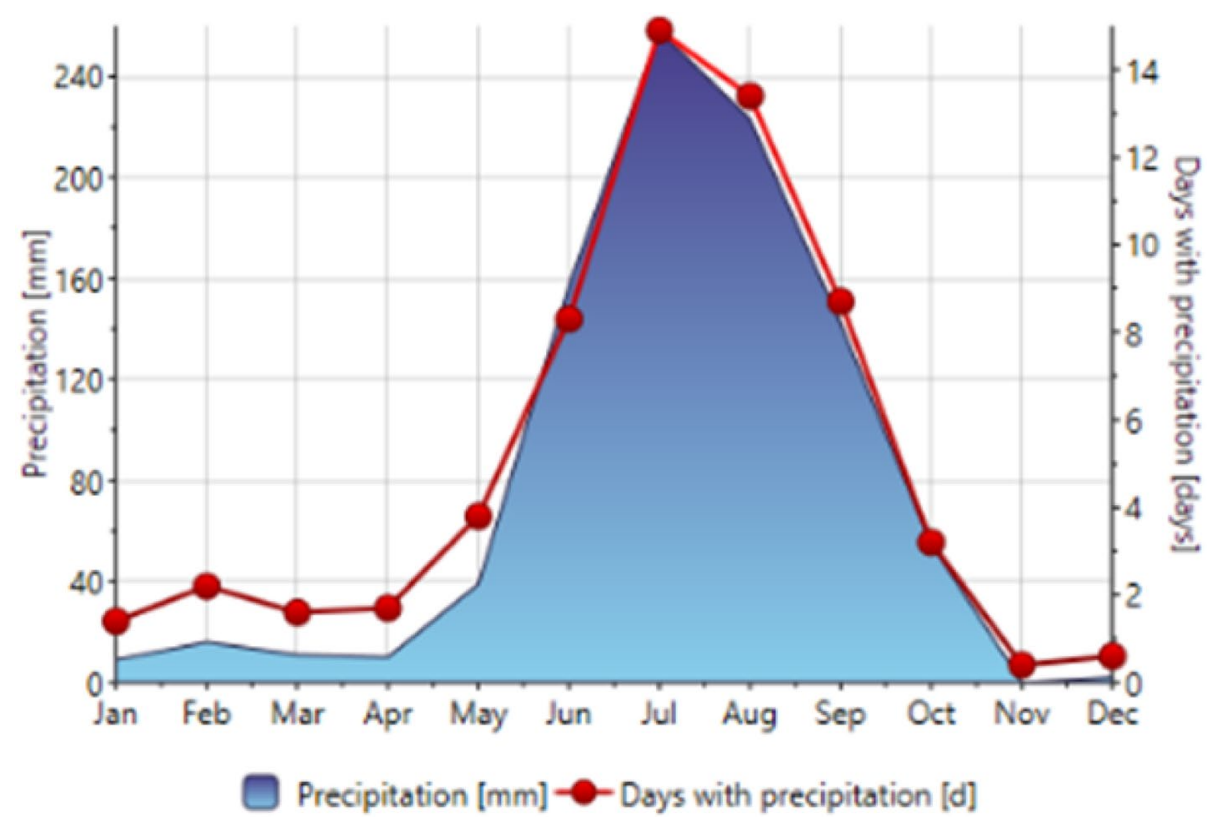

Fig. 7 The precipitation in Kathmandu

converter output and battery storage is $3345 \mathrm{kWh}$. At this stage, $4.9 \%$ is the converter loss. The energy supplied to the user is $2999 \mathrm{kWh}$. The various losses in this stage are $7.1 \%$ battery efficiency loss, $1.5 \%$ charge/discharge current efficiency loss, $1.4 \%$ electrolyte dissociation, and $0.1 \%$ battery self-discharge current. The missing energy current is $44 \mathrm{kWh}$, and the energy available to the user is $3043 \mathrm{kWh}$.

The detailed economic results show that the total yearly cost, including 9.90 inflation per year, is $\$ 1009.37 /$ year. Total usage solar energy is $2999 \mathrm{kWh} /$ year; excess energy (battery full) is $1944 \mathrm{kWh} /$ year, while the cost of energy produced (sum of the expenses over lifetime/total production over lifetime) is $0.345 \mathrm{USD} / \mathrm{kWh}$.

\section{Case 2: grid-connected PV system}

Energy balances and the main results simulated for the off-grid system are illustrated in Table 8 . For the study area, the annual global irradiance on the horizontal plane is $1869.2 \mathrm{kWh} / \mathrm{m}^{2}$, and the universal incident energy and effective global irradiance after optical losses are $2135 \mathrm{kWh} / \mathrm{m}^{2}$ and $2086.9 \mathrm{kWh} / \mathrm{m}^{2}$, respectively. The annual DC energy produced from the monocrystalline PV array and annual AC energy injected into the grid is $6111.2 \mathrm{kWh}$ and $5901.1 \mathrm{kWh}$. The yearly average performance ratio (PR) for the simulated photovoltaic system is observed to be 0.838 .

Normalised energy productions such as collection loss, system loss, and produced useful energy per installed kWh/kWp/day are shown in Fig. 10. The arrow loss diagram exhibited in Fig. 11 helps to analyse the various losses that are to be encountered while installing PV plants. Global irradiance on a horizontal plane is $1869 \mathrm{kWh} / \mathrm{m}^{2}$. Nevertheless, the effective irradiance on the collector is $2087 \mathrm{kWh} / \mathrm{m}^{2}$. This results in a gain of $14.2 \%$ global incident in the collector plane and loss of energy, i.e. $2.3 \%$ due to array incidence angle. After the PV conversion, the nominal array energy at STC is $6897 \mathrm{kWh}$. Array virtual energy at MPP is $6111 \mathrm{kWh}$. The various losses that occur in this stage are $0.4 \%$ due to irradiance level, $9.6 \%$ losses due to temperature, $1.1 \%$ loss due to module array mismatch, and $1.2 \%$ is the Ohmic wiring losses (Fig. 10). Available energy annually at the inverter output facility is $5901 \mathrm{kWh}$, and the same is available to the grid. Here the inverter loss during inverter operation was $3.4 \%$.

The detailed economic results show that the total yearly cost, including 9.90 inflation per year, is $\$ 250.59$ /year, with a produced energy of $5695 \mathrm{kWh} /$ year, and the cost of the production is $\$ 0.060$ per $\mathrm{kWh}$. The payback period is 8.7 years, and the net profit at the end of the lifetime is $\$ 1992.2$. The return on investment (ROI) is $86.6 \%$. It is also estimated that the system will save 10.33 tons of $\mathrm{CO}_{2}$ emissions (see Fig. 12).

It was observed that the power output from the solar $\mathrm{PV}$ is quite significant due to higher solar irradiance throughout the year. The electrical performance analysis and economic consideration in PVsyst for the offgrid system show that the system is feasible in terms of electrical power output, but the system is not viable 
economically. The payback period is infinite and costly because of the battery price, as the battery must be replaced in every 5 years. On the other hand, the gridconnected system is feasible in terms of electric power output and finance. The economic analysis confirms that the grid-connected PV system's payback period is 8.7 years, the rate of investment is $86.6 \%$, and $\mathrm{CO}_{2}$ saving is 10.3 tons making it environmentally friendly technology.
The comparative simulation result of the stand-alone and grid-connected system is illustrated in Table 9. The produced energy is $5.9 \mathrm{kWh} /$ year for the grid-connected system, but the used solar power for stand-alone is $2999 \mathrm{kWh} /$ year, almost half. Similarly, the cost of produce energy (sum of the expenses over lifetime/total production over lifetime) is $0.345 \mathrm{USD} / \mathrm{kWh}$ for stand-alone, and for grid-connected, it is $0.06 \mathrm{USD} / \mathrm{kWh}$. The result also showed that the stand-alone system's payback period would be indefinite because of the high battery cost and its short life cycle. The

Table 7 Balances and performances of the proposed stand-alone (off-grid) PV system in Kathmandu

\begin{tabular}{|c|c|c|c|c|c|c|c|c|}
\hline & $\begin{array}{l}\text { Glob Hor } \\
\mathrm{kWh} / \mathrm{m}^{2}\end{array}$ & $\begin{array}{l}\text { Glob Eff } \\
\mathrm{kWh} / \mathrm{m}^{2}\end{array}$ & $\begin{array}{l}\text { E_Avail } \\
\text { kWh }\end{array}$ & $\begin{array}{l}\text { E unused } \\
\text { kWh }\end{array}$ & $\begin{array}{l}\text { E_miss } \\
\text { kWh }\end{array}$ & $\begin{array}{l}\text { E_User } \\
\text { kWh }\end{array}$ & $\begin{array}{l}\text { E_load } \\
\text { kWh }\end{array}$ & $\begin{array}{l}\text { SolFrac } \\
\text { kWh }\end{array}$ \\
\hline January & 138.2 & 204.9 & 534.4 & 186.5 & 0.00 & 309.7 & 309.7 & 1.000 \\
\hline February & 140.7 & 184.0 & 469.5 & 156.1 & 0.00 & 279.8 & 279.8 & 1.000 \\
\hline March & 169.2 & 189.5 & 479.0 & 239.6 & 0.00 & 207.4 & 207.4 & 1.000 \\
\hline April & 183.7 & 180.7 & 447.2 & 223.1 & 0.00 & 200.7 & 200.7 & 1.000 \\
\hline May & 191.3 & 170.5 & 425.3 & 189.1 & 0.00 & 207.4 & 207.4 & 1.000 \\
\hline June & 175.2 & 151.1 & 378.4 & 61.0 & 0.99 & 298.7 & 299.7 & 0.997 \\
\hline July & 156.4 & 135.9 & 342.8 & 25.4 & 21.90 & 287.8 & 309.7 & 0.929 \\
\hline August & 157.5 & 146.8 & 368.4 & 56.5 & 20.21 & 289.5 & 309.7 & 0.935 \\
\hline September & 138.3 & 141.9 & 358.9 & 127.3 & 0.57 & 200.2 & 200.7 & 0.997 \\
\hline October & 148.9 & 178.5 & 450.9 & 214.9 & 0.00 & 207.4 & 2007.4 & 1.000 \\
\hline November & 131.0 & 184.8 & 472.0 & 241.8 & 0.00 & 200.7 & 200.7 & 1.000 \\
\hline December & 139.0 & 218.3 & 561.3 & 222.4 & 0.00 & 309.7 & 309.7 & 1.000 \\
\hline Total & 1869.2 & 2086.9 & 5288.2 & 1943.7 & 43.66 & 2999.2 & 3042.9 & 0.986 \\
\hline
\end{tabular}

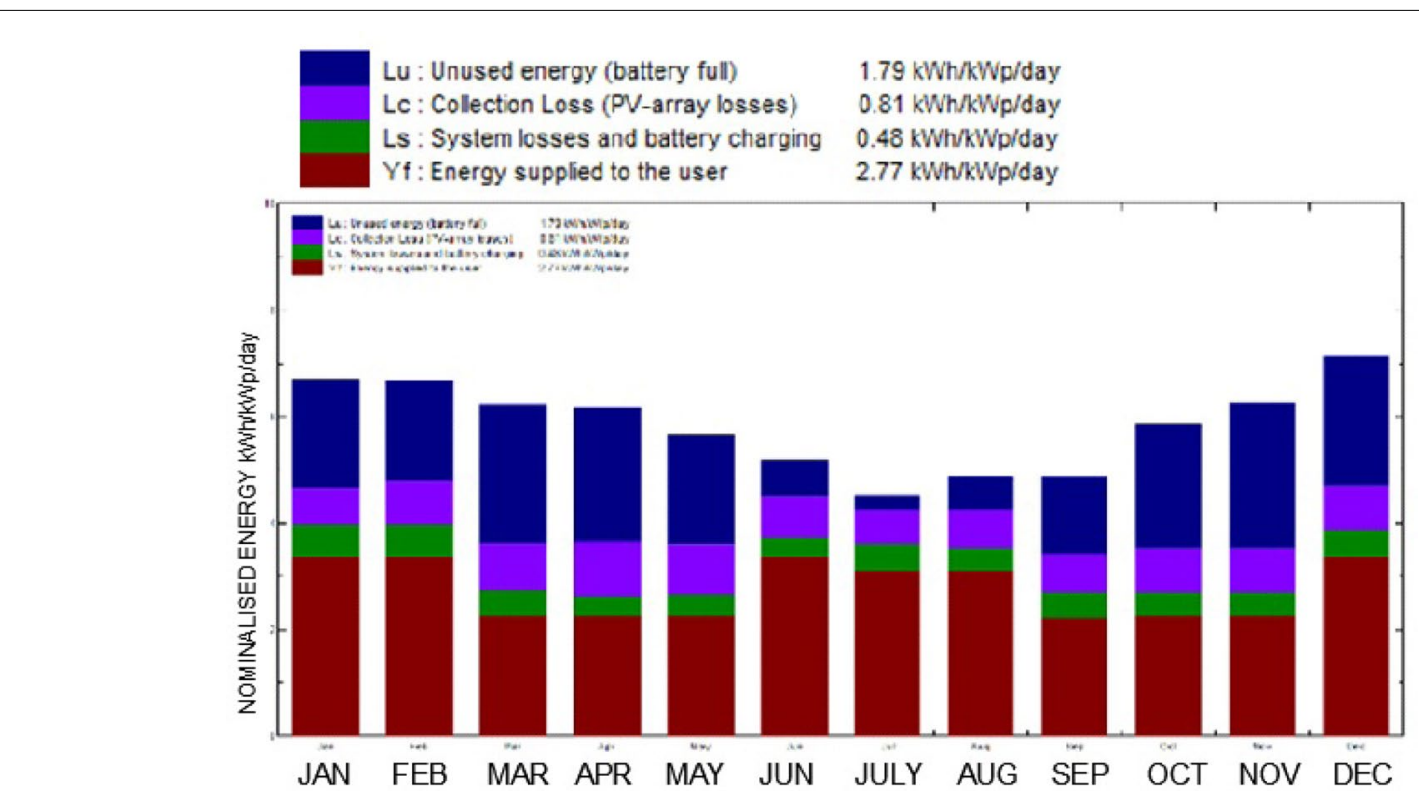

Fig. 8 Normalised energy production per installed kWp of the proposed PV system 


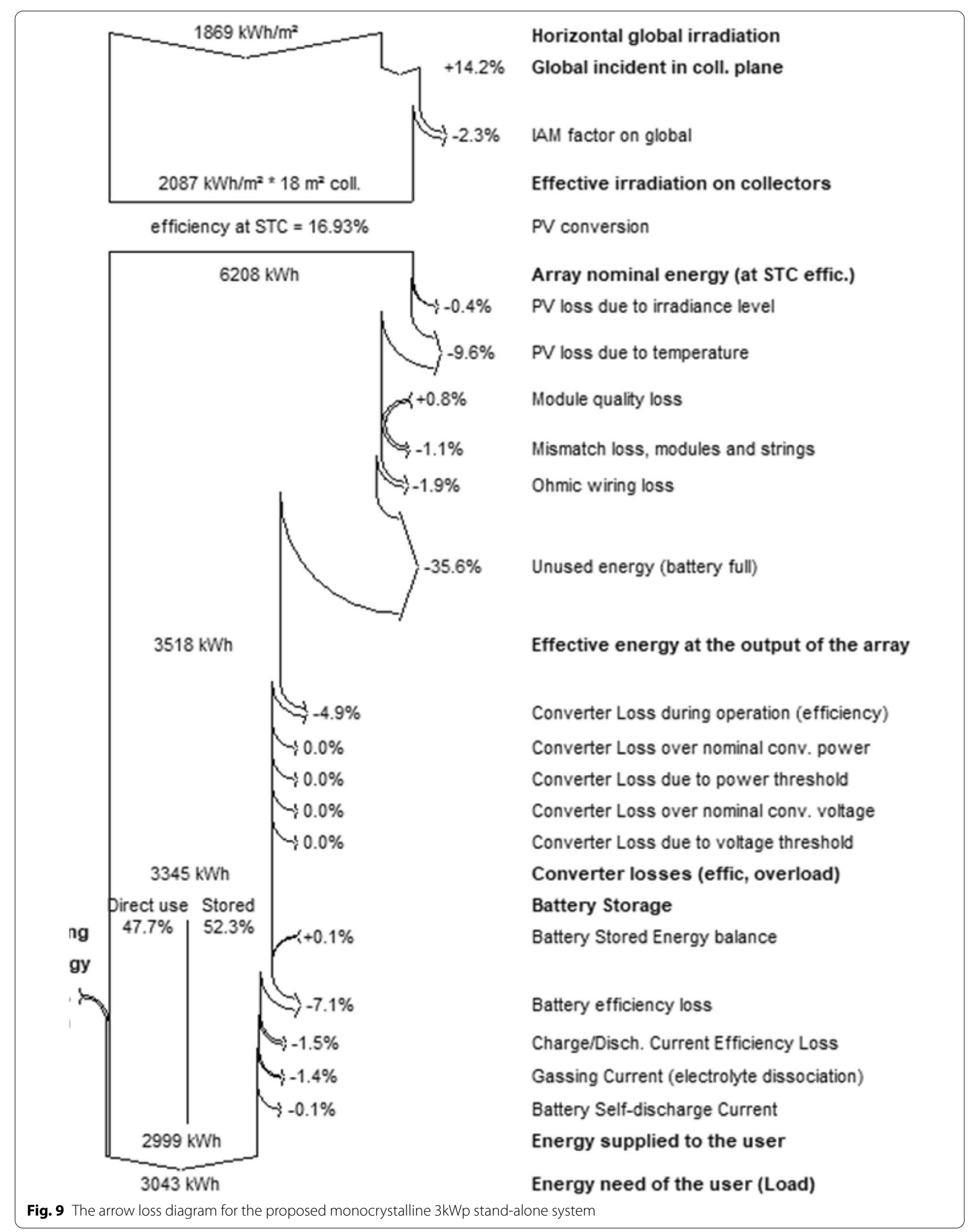


Table 8 Balances and performances of the proposed grid-connected PV system in Kathmandu

\begin{tabular}{|c|c|c|c|c|c|c|c|c|}
\hline & Glob Hor kWh/m² & Diff Hor kWh/m² & T_Amb kWh & Glob Inc kWh & Glob Eff kWh & E Arry kWh & E_Grid kWh & PR \\
\hline January & 138.2 & 25.98 & 8.90 & 208.1 & 204.9 & 618.5 & 597.9 & 0.871 \\
\hline February & 140.7 & 32.69 & 13.34 & 186.9 & 184.0 & 544.0 & 525.5 & 0.852 \\
\hline March & 169.2 & 58.43 & 18.84 & 193.7 & 189.5 & 550.0 & 531.3 & 0.831 \\
\hline April & 183.7 & 66.20 & 23.70 & 185.5 & 180.7 & 513.3 & 495.8 & 0.810 \\
\hline May & 191.3 & 77.28 & 25.06 & 175.7 & 170.5 & 489.4 & 472.2 & 0.814 \\
\hline June & 175.2 & 88.42 & 24.25 & 155.9 & 151.1 & 441.6 & 426.0 & 0.828 \\
\hline July & 156.4 & 82.90 & 23.41 & 140.5 & 135.9 & 401.7 & 386.9 & 0.835 \\
\hline August & 157.5 & 78.17 & 23.27 & 140.5 & 135.9 & 401.7 & 386.9 & 0.835 \\
\hline September & 138.3 & 70.56 & 22.40 & 146.0 & 141.9 & 414.4 & 399.8 & 0.830 \\
\hline October & 148.9 & 55.05 & 20.34 & 182.0 & 178.5 & 518.6 & 500.9 & 0.834 \\
\hline November & 131.0 & 31.37 & 15.55 & 187.9 & 184.8 & 541.8 & 523.7 & 0.844 \\
\hline December & 139.0 & 19.92 & 11.06 & 221.5 & 218.3 & 648.0 & 626.4 & 0.857 \\
\hline Total & 1869.2 & 686.98 & 19.20 & 2135.0 & 2086.9 & 6111.2 & 5901.1 & 0.838 \\
\hline
\end{tabular}
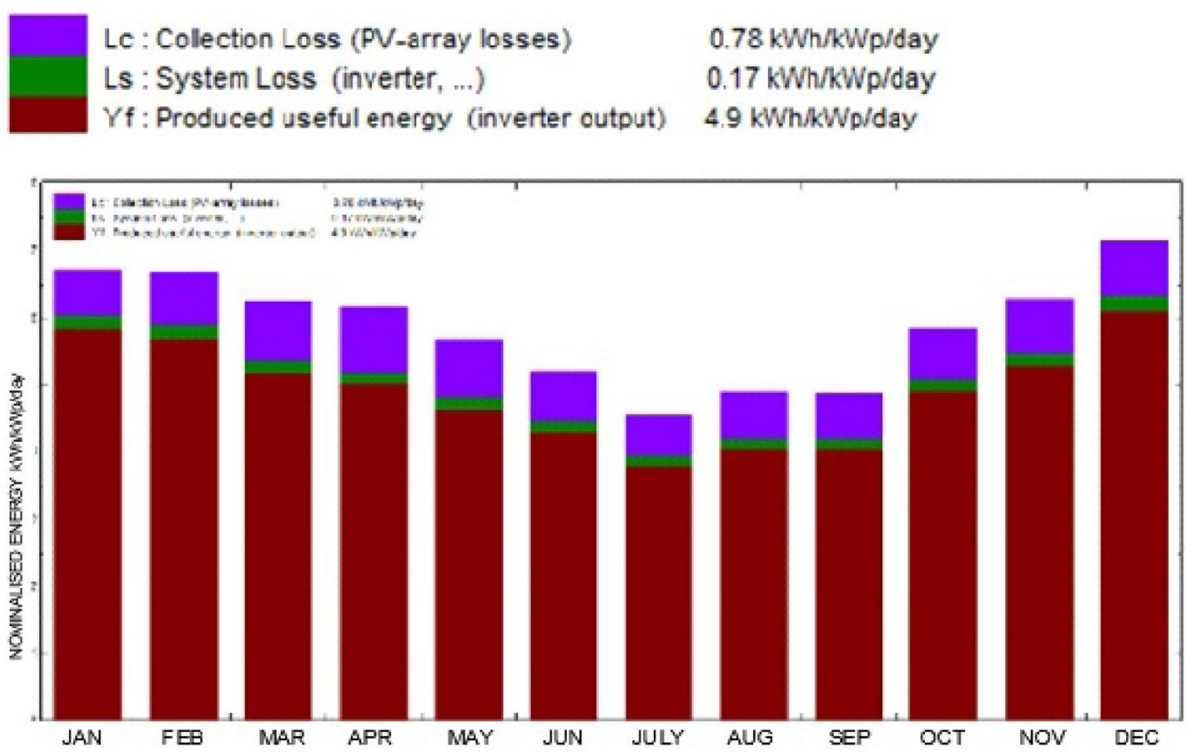

Fig. 10 Normalised energy production per installed kWp of proposed PV system

preliminary investment, operation, and maintenance costs are higher compared to the grid-connected system. The low electricity price also outweighed the cost, therefore, making the investment infeasible.

Nonetheless, this system has the added advantages of supporting reducing $\mathrm{CO}_{2}$ emissions and a yearly reduction in electricity bills, which will go higher in the coming years. The system is also independent of a grid system; therefore, the power outage and the voltage fluctuation in the grid will not be affected. Furthermore, projections show that the plans can be feasible if the declining trend in PV system prices continues, and electricity prices increase. For the grid-connected system, the payback period is 8.7 years, the net profit at the end of the lifetime is USD 1992.15, and the return of investment (ROI) is $86.6 \%$. The system is, therefore, techno-economically viable.

Hence the effective use of storage and cost of the battery will play a pivotal role in the decision-making of installing the system. The simulated result showed that both systems have advantages and are technically viable. The solar-grid system is the best option between the two proposed systems, exceptionally, when there is a reliable grid connection. Nevertheless, if there is no grid connection, then the stand-alone design can be cheaper than extending power lines like in some remote regions. 


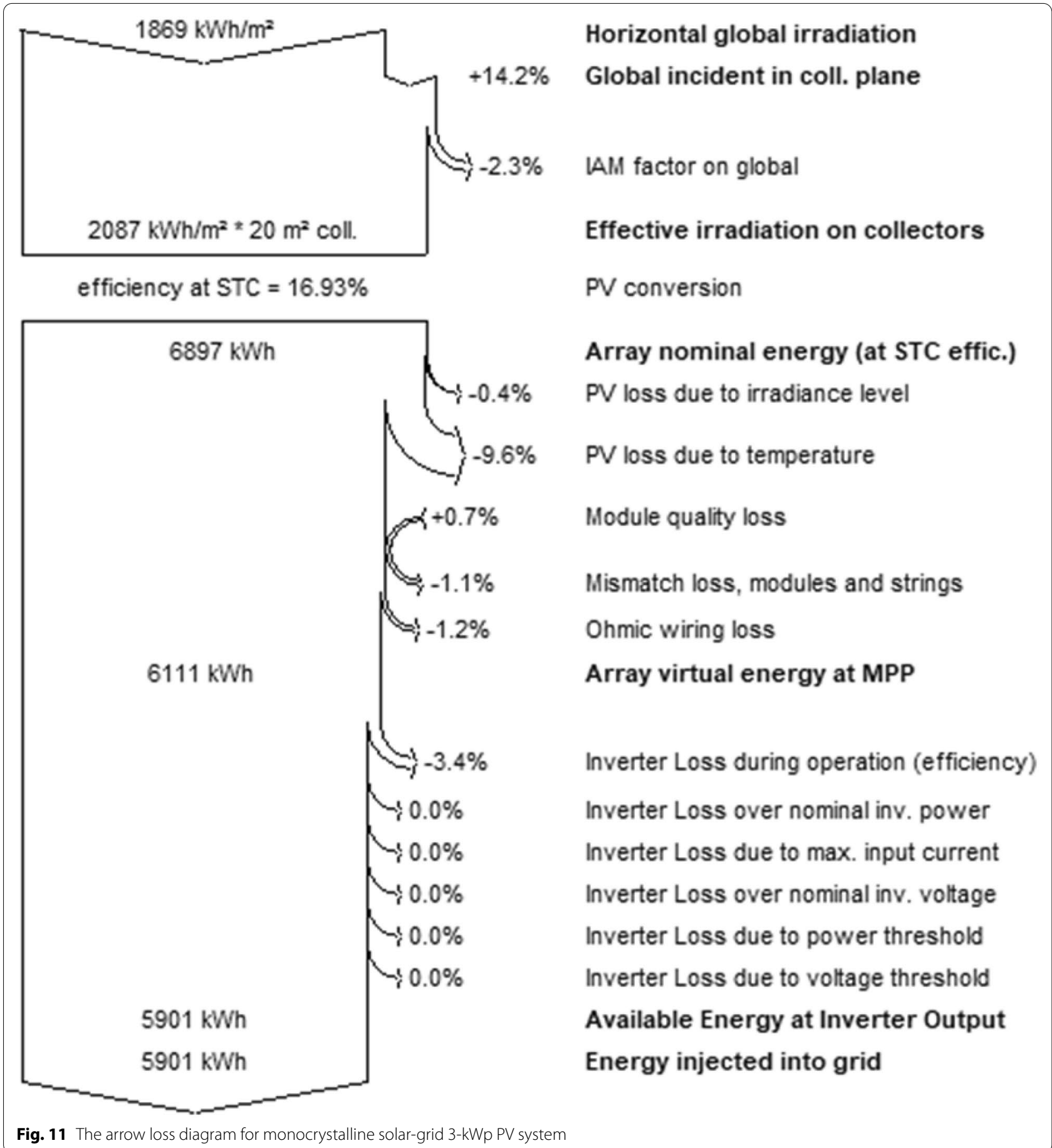

Noteworthy, Nepal receives a high amount of solar radiation throughout the year. The data obtained from Meteonorm showed that the horizontal yearly irradiation in Kathmandu is $1950 \mathrm{kWh} / \mathrm{m}^{2} /$ year and has moderate temperature throughout the year, having an average maximum temperature of $25.7{ }^{\circ} \mathrm{C}$ and a minimum average temperature of $11.4{ }^{\circ} \mathrm{C}$. The weather data analysis demonstrated that the PV power plant is promising in the Kathmandu valley, generating electricity for public consumption. Similarly, the simulation result in PVsyst proved an enormous potential for solar PV systems in Kathmandu. 


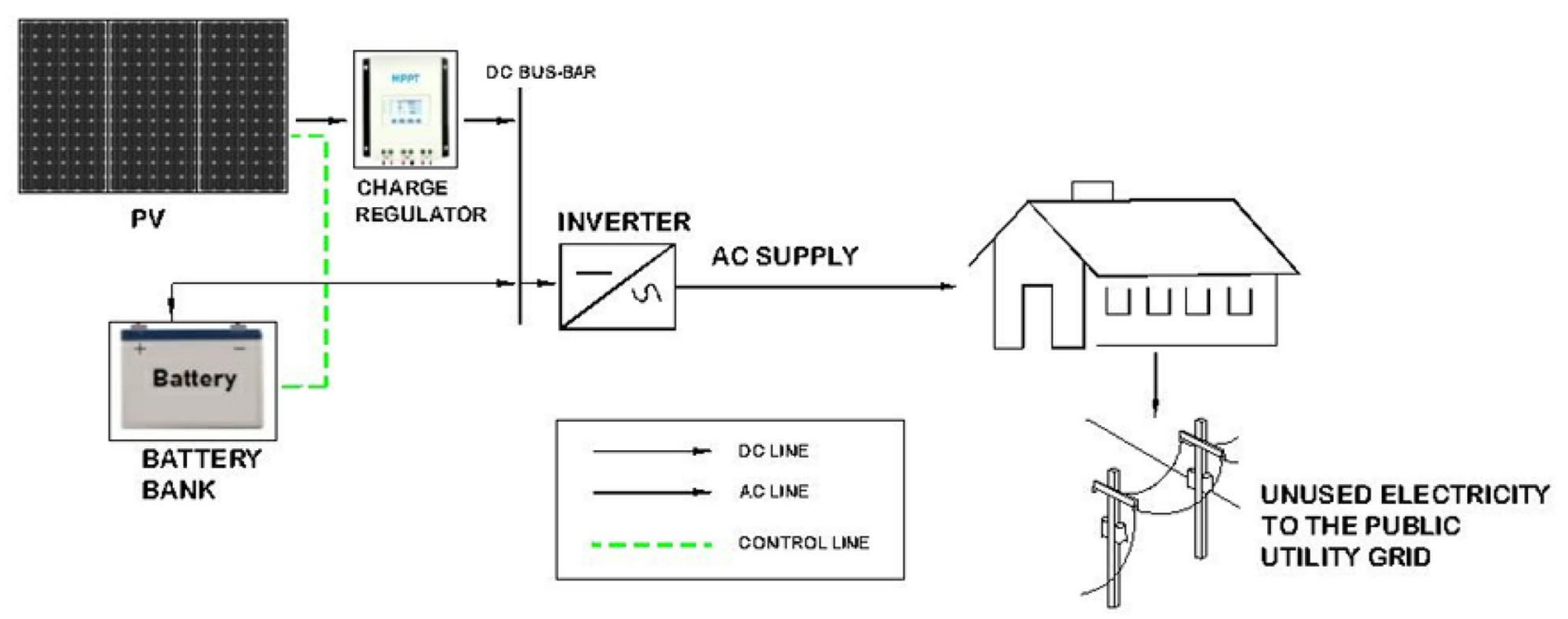

Fig. 12 The block diagram of the proposed PV system for Kathmandu

Table 9 Comparison between of a stand-alone and grid-connected proposed PV system

\begin{tabular}{lll}
\hline & Standalone PV system & Grid-connected PV system \\
\hline Total yearly cost including inflation & $\$ 1009.37$ USD /year & \$145.89USD /year \\
Produced energy & $2999 \mathrm{kWh} /$ year & $5.9 \mathrm{MWh} /$ year \\
Payback period & Indefinite & 8.7 years \\
Net profit at the end of the lifetime & - & $\$ 1992.2 \mathrm{USD}$ \\
Return of investment (ROI) & - & $86.60 \%$ \\
Used energy cost & $0.345 \mathrm{USD} / \mathrm{kWh}$ & 0.060 USD/kWh \\
$\mathrm{CO}_{2}$ emissions saved & 5.0 tons & 10.3 tons \\
\hline
\end{tabular}

\section{Discussion}

\section{Development and challenges in solar PV deployment}

Solar energy deployment has experienced unprecedented growth in recent years. Solar prices have decreased considerably over the last decade. New installation of solar PV system surpassed all other renewable energy globally (Cox et al., 2015). Despite these, Surendra. et al. (2011) also argued that solar PV is weather-dependent and fails to provide households with a consistent energy supply. It is not suitable in the region with long and harsh winters as the temperature falls below freezing. Therefore, developing an effective and stable system for evaluating solar PV site selection is an essential and incredibly challenging task. This section illustrates the opportunities and challenges of the proposed method and outlines the management implications. Despite the critical expansion of the solar market in many countries, barriers to solar deployment still exist. Common critical barriers include (Cox et al., 2015) below:
- Restrictive and time-consuming regulatory and permitting processes;

- Technical or infrastructural grid integration challenges;

- Lack of reliable policy signals, which can create uncertainty in markets;

- The concern of utilities related to the integration of distributed or variable power in the grid;

- The higher cost of solar technologies in comparison with other technologies;

- Lack of affordable financing;

- Need for a skilled workforce to design, instal, and operate and maintenance.

\section{Support mechanisms relevant for Nepal}

In order to achieve the target set by the GON to reach $100 \%$ electrification by 2023 (Poudyal et al., 2020) and maintain the renewable energy contribution to $30 \%$ 
by 2030 (Poudyal et al., 2019b), the Government has to design policies that support the unique national situation and objective. Many studies that have been done globally showed the viability of promoting solar PV systems in the total energy mix. These studies have investigated the various approaches and techniques to determine PV systems' techno-economic suitability (Chandel et al., 2014; Fan et al., 2017; Garba et al., 2021; Lopez-Vidana, 2021; Sathaye et al., 2011). Among the developing countries, studies are mainly concentrated on countries like India and China (Bhat et al., 2019, Chandel et al., 2014, Kumar et al., 2020, Sontake \& Kalamkar, 2016, Sontake et al., 2020a, b, Tang et al., 2010, Thotakura et al., 2020, Tiwari et al., 2020a, b, Verma \& Dondapati, 2017). Nepal has also initiated research and development in the sector, but they are minimal (AEPC, 2020; Bajracharya \& Maharjan, 2019; Chianese, 2010; Poudyal et al., 2020; Shrestha \& Nath Shrestha, 2013). Moreover, Sapkota (2020) provides a comprehensive review of the status of solar PV in Nepal. These studies suggested that the support mechanisms required to promote RET are mostly related to the provision of: flexible financial instruments, ensuring financial innovations, the building of PV systems for concentrated energy loads, adopting standards process of technical appraisals, and local capacity building. Similarly, Bhusal (2019) mentions an incompetent subsidy model for renewable energy investment. Nepal's faltering renewables policy may find its solution in energy tradehydro, RE from India.

India and China are energy-hungry nations set to consume half of the world's energy by 2030. For this, India has been aggressively investing in solar PV systems with a target of $100 \mathrm{GW}$ of installed solar capacity by 2022 , and likewise, China has a similar target within 2020. This is the biggest inspiration for Nepal. Nepal should follow its footstep to enhance its energy system by adapting the solar PV system to its energy mix.

Enhanced penetration of RETs in Nepal requires an improved financial innovation and an upscaled involvement of private sectors (Palit \& Chaurey, 2011). Innovative financing schemes, such as increasing access to the lenders to long-term credits or low-interest loans to implementing organisations and households, are also relevant. Indirectly, the Government can facilitate to increase access to credit by information campaigns targeted at financial institutions. There are also concerns due to political stability, good governance, and the implementation of regulatory frameworks to successfully upscale alternative energy technologies, including solar PV (Dhakal et al., 2019). For effective implementation of renewable energy policies, the GoN should also ensure proper budgets, particularly for the country's nationally accredited renewable energy programme and projects. Another essential aspect primarily suggested is, the need to restructure the current institutional frameworks involved in the renewable energy development and promotion sectors, mainly to effectively mobilise regulatory bodies and private sectors (for both promotions and after-sales services) (Parajuli, 2011). Capacity development and institutional strengthening are thus vital (Parajuli, 2011). At the consumer level, it is also imperative that consumer-based awareness towards effective energy utilisation and energy management is facilitated. Based on the experiences observed in the implementation and operation of different policy mechanisms for enhanced use of RETs in various countries, it can be said that the Feed-in-tariff (FIT) can also be highly effective in Nepal. Formulation of effective FIT can help to promote the interconnection of a solar PV system with the grid. Although this could be limited for a small scale and scattered installations at residential dwellings. However, the GoN should need to explore alternative funding mechanisms that can cover the additional costs of generation, mainly to reduce utilities' burden and reduce the unintended cost increase in the consumers' electricity bills. This can be facilitated through different financing options and subsidies that can mainly reduce the cost of generation (i.e. on the grid interconnection equipment costs) (Shrestha, 2017).

\section{Conclusion}

This article's novelty considers system optimisation possibilities and the assessment of locally available renewable energy resources, completely based on local weather conditions, irradiations, temperature, and geographic situation. As per the result of this research, it is evident that the grid-connected system is economically available. However, all PV systems could be adapted to make a balance in the annual rising electricity demand. A stand-alone PV system would be beneficial for rural areas where there is no grid connection. Likewise, the gridconnected would be helpful in urban areas. Government policies and necessary implementations can play crucial roles in developing this decentralised energy system. In addition, the GoN should consider the solar-powered PV system from a broader perspective. For example, if $1,00,000$ homeowners of Kathmandu valley installed a 3-kW PV system, then $300 \mathrm{MW}$ electricity could be generated. Hence, this can increase attention towards the formulation and implementation of conducive policy and support mechanisms. While solar PV by itself cannot solve future planning and supply issues, it can certainly play a significant role in meeting a sizeable portion of annual demand. However, to our knowledge, an extensive evaluation of rooftop PV solar potential has not yet been undertaken in this city and country on a broader scale. 
Several barriers still hinder the full development and installation of solar PV-grid technology in Nepal. This study can be regarded as a milestone for further recommending society towards adopting integrated renewable energy technologies in Nepal.

\begin{abstract}
Abbreviations
AC: Alternative current; BTU: British thermal unit; DC: Direct current; DiffHor: Difference horizontal; E_Avail: Energy availability; E_Grid: Energy grid; E_Load: Energy load; E_Miss: Energy miss; E_User: Energy user; EArray: Energy array; F.Y: Fiscal year; FIT: Feed in tariff; GlobEff: Global efficiency; GlobHor: Global horizontal; Globlnc: Global inclination; Lc: Collection loss; Ls: System loss; Lu: Unused energy; NEA: Nepal electricity authority; NRs: Nepalese rupees; PR: Performance ratio; RETs: Renewable energy technologies; SolFrac: Solar fraction; SPV: Solar photovoltaic; SPC: Solar power company; STC: Standard test condition; T_Amb: Ambient temperature; TPEC: Total primary energy consumption; Yf: Produced useful energy (inverter output); \$: US dollar.
\end{abstract}

\section{Acknowledgements}

Not applicable

\section{Authors' contributions}

RHP conceptualised, analysed, and wrote the original manuscript; RP supported the article preparation, review, and editing; and PL supported in supervision, reviewing, and editing. All authors have read and approved the final manuscript.

\section{Funding}

The authors declare that there is no external funding for the study.

\section{Availability of data and materials}

The datasets used and/or analysed during the current study are available from the corresponding author on reasonable request.

\section{Declarations}

\section{Ethics approval and consent to participate}

We all authors confirm that the appropriate ethics approval and consent to participate are not needed

\section{Consent for publication}

The authors have granted consent for publication.

\section{Competing interests}

The authors declare that they have no competing interests.

\section{Author details}

'Swansea University, Fabian Way, Crymlyn Burrows, Skewen, Swansea SA1 8EN, UK. ${ }^{2}$ ZJU-UIUC Institute, Engineering Bld, 718 East Haizhou Road, Haining 314400, Zhejiang, China. ${ }^{3}$ Ralph E. Martin Department of Chemical Engineering, University of Arkansas, Fayetteville, AR 72701, USA.

Received: 1 November 2020 Accepted: 26 May 2021 Published online: 27 June 2021

\section{References}

Administration, U. S. E. I. (2019).International energy outlook 2019 with projections to 2050. Choice Rev Online. https://doi.org/10.5860/CHOICE.44-3624.

AEPC. Urban Solar Rooftop Programme, Nepal. (2020) https://www.aepc.gov.np/ urbansolar/. Accessed 6 Jan 2021.

Al Garni, H., \& Awasthi, A. (2017). Techno-economic feasibility analysis of a solar PV grid-connected system with different tracking using HOMER software. 2017 5th IEEE International Conference on Smart Energy Grid Engineering (SEGE). https://doi.org/10.1109/SEGE.2017.8052801.
Ashok Kumar, L., Indragandhi, V., \& Uma Maheswari, Y. (2020). PVSYST Software tools for the simulation of electrical system. Cambridge: Academic press.

Astriani, Y., Shafiullah, G. M., Anda, M., \& Hilal, H. (2019). Techno-economic evaluation of utilizing a small-scale microgrid. Energy Procedia. https://doi.org/10. 1016/j.egypro.2019.01.1013

Awasthi, J., \& Poudyal, K. N. (2018). Estimation of global solar radiation using empirical model on meteorological parameters at Simara airport Bara, Nepal. Journal of the Institute of Engineering. https://doi.org/10.3126/jie.v14i1.20078.

Bajracharya, S. (2019). Grid-connected solar system: New step in Nepal's energy mix. The Himalayan Times. Himal Times. https://thehimalayantimes.com/opini on/grid-connected-solar-system-new-step-in-nepals-energy-mix/. Accessed 3 Dec 2019.

Bajracharya S. M., \& Maharjan, S. (2019). Techno economic analysis of grid tied solar system: A case study of Nepal Telecom, Sundhara, Kathmandu, Vol. 7, Proceedings of IOE Graduate Conference. http://conference.ioe.edu.np/publi cations/ioegc2019-winter/IOEGC-2019-Winter-28.pdf. Accessed 6 Jan 2021.

Basnett, Y., Henley, G., Howell, J., Jones, H., Lemma, A., \& Pandey, P. R. (2014). Shaping policy for development structural economic transformation in Nepal A diagnostic study submitted to DFID Nepal.

Bhat, K. S., Bachhiesl, U., Feichtinger, G., \& Stigler, H. (2019). Techno-economic model-based analysis of the renewable energy transition in the Indian subcontinent region. Inftech Elektrotech. https://doi.org/10.1007/ s00502-019-00773-W.

Bhattacharjee, S., \& Dey, A. (2014). Techno-economic performance evaluation of grid integrated PV-biomass hybrid power generation for rice mill. Sustainable Energy Technologies and Assessments. https://doi.org/10.1016/j.seta. 2014.02.005

Bhattacharyya, S. C. (2013). Financing energy access and off-grid electrification: A review of status, options, and challenges. Renewable and Sustainable Energy Reviews. https://doi.org/10.1016/j.rser.2012.12.008.

Bhusal, R. (2019). Subsidies killing renewable energy investments in Nepal |The Third Pole. Third Pole:2. https://www.thethirdpole.net/2019/08/05/subsi dies-killing-renewable-energy-investments-in-nepal/. Accessed 8 Jan 2021.

Blanco, J., \& Malato, S. (2009). Solar energy conversion and photoenergy system volume ll google books. Oxford: Eolss Publ Co Ltd.

Cassard, H., Denholm, P., \& Ong, S. (2011). Technical and economic performance of residential solar water heating in the United States. Renewable and Sustainable Energy Reviews. https://doi.org/10.1016/..rser.2011.07.016.

Chandel, M., Agrawal, G. D., Mathur, S., \& Mathur, A. (2014). Techno-economic analysis of solar photovoltaic power plant for garment zone of Jaipur city. Case Studies in Thermal Engineering. https://doi.org/10.1016/j.csite.2013.10. 002.

Chianese, D., Pittet, D., Shrestha, J. N., Sharma, D., Zahnd, A., Upadhyaya, M. R., et al. (2010). Development of PV grid-connected plants in Nepal, Nepal CES-TU / NSES 2010.

Commission I-IE. IEC 61724. (1998). Photovoltaic system performance monitoring - guidelines for measurement, data Exchange, and analysis | Engineering360. IEC-International Electrotechnical Commission, 46. https://standards. globalspec.com/std/29890/IEC 61724, Accessed 2 Mar 2020.

Cox, S., Walters, T., Esterly, S., Booth, S., Clean, B., \& LIc, E. (2015). Solar power: Policy overview and good practices. https://www.nrel.gov/docs/fy15osti/ 64178.pdf. Accessed 2 Mar 2020.

Dhakal, S., Srivastava, L., Sharma, B., Palit, D., Mainali, B., Nepal, R., et al. (2019). Meeting future energy needs in the Hindu Kush Himalaya. Hindu Kush Himalaya Assess. https://doi.org/10.1007/978-3-319-92288-1_6.

El Gayar, O., \& Anthony, M. (2010). The Solar and wind energy resource assessment (SWERA) Decision support system (DSS) Benchmarking Report.

Fan, J. L., Zhang, Y. J., \& Wang, B. (2017). The impact of urbanization on residential energy consumption in China: An aggregated and disaggregated analysis. Renewable and Sustainable Energy Reviews, 75, 220-233. https://doi.org/10. 1016/j.rser.2016.10.066.

Fath, H. E. S. (1995). Thermal performance of a simple design solar air heater with the built-in thermal energy storage system. Renewable Energy. https://doi. org/10.1016/0960-1481(94)00085-6.

Garba I et al. (2021). Energy poverty: Estimating the impact of solid cooking fuels on GDP per Capita in developing countries-case of sub-Sahara Africa-ScienceDirect n.d. https://www.sciencedirect.com/science/article/pii/S0360 544221000190?dgcid=raven_sd_aip_email. Accessed 7 Jan 2021.

Ghasemi, A., Asrari, A., Zarif, M., \& Abdelwahed, S. (2013). Techno-economic analysis of stand-alone hybrid photovoltaic-diesel-battery systems for rural electrification in the eastern part of Iran — a step toward sustainable rural 
development. Renewable and Sustainable Energy Reviews. https://doi.org/10. 1016/j.rser.2013.08.011.

Government of Nepal. (2013). Ministry of Science Technology and Energy, Alternative Energy Promotion Centre. Alternative Energy Promotion Centre Renewable Energy Subsidy Delivery Mechanism.

Haghighat Mamaghani, A., Avella Escandon, S. A., Najafi, B., Shirazi, A., \& Rinaldi, F. (2016). Techno-economic feasibility of photovoltaic, wind, diesel, and hybrid electrification systems for off-grid rural electrification in Colombia. Renewable Energy. https://doi.org/10.1016/j.renene.2016.05.086.

IHA. (2020). Hydropower status report. (2020). https://doi.org/10.1103/PhysR evLett.111.027403.

IRENA. (2014). International renewable energy agency. The Socio-economic Benefits of Solar and Wind Energy, 108.

Irwan, Y. M., Amelia, A. R., Irwanto, M., Fareq, M., Leow, W. Z., Gomesh, N., et al. (2015). Stand-alone photovoltaic (SAPV) system assessment using PVSYST software. Energy Procedia. https://doi.org/10.1016/j.egypro.2015.11.539.

Jäger-Waldau, A., Kougias, I., Taylor, N., \& Thiel, C. (2020). How photovoltaics can contribute to GHG emission reductions of 55\% in the EU by 2030. Renewable and Sustainable Energy Reviews. https://doi.org/10.1016/j.rser.2020. 109836.

Jäger-Waldau, A., Szabó, M., Scarlat, N., \& Monforti-Ferrario, F. (2011). Renewable electricity in Europe. Renewable and Sustainable Energy Reviews. https://doi.org/10.1016/j.rser

Karki, P., Adhikary, B., \& Sherpa, K. (2012). Comparative study of grid-tied photovoltaic (PV) system in Kathmandu and Berlin using PVsyst. In 2012 IEEE Third International Conference on Sustainable Energy Technologies (ICSET), IEEE.

Kathmandu Post. (2020). Plan for the airport in Bhairahawa to be fully solarpowered gains momentum. https://kathmandupost.com/national/2020/ 11/28/plan-for-airport-in-bhairahawa-to-be-fully-solar-powered-gainsmomentum. Accessed 5 Jan 2021.

Kazem, H. A., Albadi, M. H., Al-Waeli, A. H. A., Al-Busaidi, A. H., \& Chaichan, M. T. (2017). Techno-economic feasibility analysis of $1 \mathrm{MW}$ photovoltaic gridconnected system in Oman. Case Studies in Thermal Engineering. https://doi. org/10.1016/j.csite.2017.05.008.

Kumar, S. (2020). Policy implications for up-scaling of off-grid solar PV for increasing access to electricity in rural areas of Nepal. Best Practices and Lessons Learned, 6, 8-20.

Kumar, N. M., Sudhakar, K., \& Samykano, M. (2020). Performance comparison of BAPV and BIPV systems with c-Si, CIS, and CdTe photovoltaic technologies under tropical weather conditions. Case Studies in Thermal Engineering, 2019, 13. https://doi.org/10.1016/..csite.2018.100374.

Lopez-Vidana, E., et al. (2021). Energy and exergy analyses of a mixed-mode solar dryer of pear slices (Pyrus communis L). Energy. https://doi.org/10.1016/J. ENERGY.2020.119740.

Llamas, B., \& de Adana, R. (2019). Optimization of 100 MWe parabolic-trough solar-thermal power plants under regulated and deregulated electricity market conditions. Energies, 12, 3973. https://doi.org/10.3390/en12203973.

Mainali, B., \& Silveira, S. (2012). Renewable energy markets in rural electrification: Country case Nepal. Energy for Sustainable Development, 2012(16), 168-178. https://doi.org/10.1016/J.ESD.03.001.

Mathew, S. (2007). Fundamentals, resource analysis, and economics. Wind Energy. https://doi.org/10.1007/3-540-30906-3

Ministry of finance. Economic survey ministry of finance (2017).https://doi.org/ 10.1016/B978-1-4160-5198-5.00016-2.

Nepal Electricity Authority. (2020). Nepal electricity authority a year in reviewThe fiscal year 2019/2020. Kathmandu.

Nepal Investment Bank Limited. (2020). Home and Solar LoanNepal Investment Bank Limited. Nepal InvestBankLtd. https://www.nibl.com.np/index.php? option=com_content\&view=article\&id=191\&ltemid=130. (Accessed Mar 22020).

Nepal Rastra Bank. (2018.). Monetary Policy for 2018/19

Palit, D., \& Chaurey, A. (2011). Off-grid rural electrification experiences from South Asia: status and best practices. Energy for Sustainable Development, 15, 266-276. https://doi.org/10.1016/j.esd.2011.07.004.

Parajuli, R. (2011). Access to energy in Mid/Far west region-Nepal from the perspective of energy poverty. Renewable Energy, 2011(36), 2299-2304. https:// doi.org/10.1016/j.renene.01.014

Parajuli, R., Østergaard, P. A., Dalgaard, T., \& Pokharel, G. R. (2014). Energy consumption projection of Nepal: Aneconometricapproach. Renewable Energy, 63, 432-444. https://doi.org/10.1016/j.renene.2013.09.048.
Parajuli, R., Pokharel, G. R., \& Østergaard, P. A. (2012). A comparison of diesel, biodiesel, and solar PV-based water pumping systems in the context of rural Nepal. International Journal of Sustainable Energy, 2014(33), 536-553. https:// doi.org/10.1080/14786451

Pillai, G., Hodgson, J., Insaurralde, C. C., Pinitjitsamut, M., \& Deepa, S. (2016). The techno-economic feasibility of providing solar photovoltaic backup power. International Symposium on Technology and Society. https://doi.org/10. 1109/ISTAS.7764051.

Poudyal, R. (2017). Struggle for power - Oped - The Kathmandu Post. http:// kathmandupost.ekantipur.com/news/2017-12-07/struggle-for-power.html. Accessed 2 Jan 2018.

Poudyal, R. (2019). Sustainable energy future: Energy mix is the key | The Himalayan Times. Himal Times.

Poudyal, R., et al. (2020). Modelling and simulation of solar photovoltaic rooftop: Case of Kathmandu. In Shrestha, B. et al. (Eds.), Promoting cultural change in engineering practices for the Development of Nepal: Learning from the UK ( $p$. 80). London: Society of Nepalese Engineers UK.

Poudyal, K. N., Bhattarai, B. K., Sapkota, B., \& Kjeldstad, B. (1970). Solar radiation potential at four sites of nepal. Journal of the Institute of Engineering. https:// doi.org/10.3126/jie.v8i3.5944.

Poudyal, R., Loskot, P., \& Parajuli, R. (2019a). Innovative technologies and sustainable Practices in the energy sector to overcome the energy crisis of Nepal. In B. Shrestha, et al. (Eds.), Innovative Technologies and Practices for Nepal (p. 112). London: UK

Poudyal, R., Loskot, P., Nepal, R., Parajuli, R., \& Khadka, S. K. (2019b). Mitigating the current energy crisis in Nepal with renewable energy sources. Renewable and Sustainable Energy Reviews. https://doi.org/10.1016/j.rser.2019.109388.

Poudyal, R., Parajuli R., Loskot P. (2020). Modelling and simulation of solar photovoltaic rooftop: The case of Kathmandu, 4th International Conference SONE/UK, London: Society of Nepalese Engineers UK, p. 110

Rehman, S., \&El-Amin, I. (2012). Performance evaluation of an off-grid photovoltaic system in Saudi Arabia. Energy, 46, 451-458. https://doi.org/10.1016/j. energy.2012.08.004

Sathaye, J., Lucon, O., Rahman, A., Christensen, J., Denton, F., Fujino, J., et al. (2011). Chapter 9-Renewable energy in the context of sustainable development. IPCC Special Report on Renewable Energy Sources Climate Change and Mitigation. https://archive.ipcc.ch/pdf/special-reports/srren/drafts/Chapt er\%2009\%20SOD.pdf.

Shahzad, M. K., Zahid, A., Rashid, T., Rehan, M. A., Ali, M., \& Ahmad, M. (2017). Techno-economic feasibility analysis of a solar-biomass off-grid system for the electrification of remote rural areas in Pakistan using HOMER software. Renewable Energy. https://doi.org/10.1016/j.renene.

Shrestha, Z. (2017). Implementing renewable energy feed-in tariffs in Nepal. REnergizing Growth. http://www.windpowernepal.com/implementing-renew able-energy-feed-in-tariffs-in-nepal/. Accessed 5 Jan 2021.

Shrestha, U., \& Nath Shrestha J. A. (2013). A techno-economic analysis of utilityscale photovoltaic plant (A Case Study of 1 MWp Plant at Trishuli). 2015. https://www.semanticscholar.org/paper/A-Techno-Economic-Analysis-ofUtility-Scale-Plant-(-Shrestha-Shrestha/2c49addc53484f78f68cef9f60baea 1fd6c50709. Accessed 6 Jan 2021.

Sontake, V. C., \& Kalamkar, V. R. (2016). Solar photovoltaic water pumping system - A comprehensive review. Renewable and Sustainable Energy Reviews. https://doi.org/10.1016/..rser.2016.01.021.

Sontake, V. C., Tiwari, A. K., \& Kalamkar, V. R. (2020a). Performance investigations of solar photovoltaic water pumping system using centrifugal deep well pump. Thermal Science. https://doi.org/10.2298/TSCl180804282S.

Sontake, V. C., Tiwari, A. K., \& Kalamkar, V. R. (2020b). Experimental investigations on the seasonal performance variations of directly coupled solar photovoltaic water pumping system using centrifugal pump. Environment, Development and Sustainability. https://doi.org/10.1007/s10668-020-00965-x.

Statista. (2019). Nepal Trade balance from 2009 to 2019. Statista. https://www. statista.com/statistics/425787/trade-balance-of-nepal/. Accessed 5 Jan 2021.

Surendra, K. C., Khanal, S. K., Shrestha, P., \& Lamsal, B. (2011). Current status of renewable energy in Nepal: Opportunities and challenges. Renewable and Sustainable Energy Reviews, 15, 4107-4117. https://doi.org/10.1016/J.RSER. 2011.07.022.

Tang, X., Quan, Z., \& Zhao, Y. (2010). Experimental investigation of solar panel cooling by a novel micro heat pipe array. Energy and Power Engineering, 02, 171-174. https://doi.org/10.4236/epe.2010.23025. 
Thotakura, S., Kondamudi, S. C., Xavier, J. F., Quanjin, M., Reddy, G. R., Gangwar, P. et al. (2020). Operational performance of megawatt-scale grid integrated rooftop solar PV system in tropical wet and dry climates of India. Case Studies in Thermal Engineering, 18, 100602. https://doi.org/10.1016/j.csite. 2020.100602

Tiwari, A. K., Kalamkar, V. R., Pande, R. R., Sharma, S. K., Sontake, V. C., \& Jha, A. (2020a). Effect of head and PV array configurations on solar water pumping system. Materials Today Proceedings. https://doi.org/10.1016/j.matpr.2020. 09.200.

Tiwari, A. K., Sontake, V. C., \& Kalamkar, V. R. (2020b). Enhancing the performance of solar photovoltaic water pumping system by water cooling over and below the photovoltaic array. Journal of Solar Energy Engineering, 10(1115/1), 4044978.

UNEP. (2019). Production Gap Report 2019 | UNEP - UN Environment Programme. https://www.unenvironment.org/resources/report/productiongap-report. Accessed 5 Jan 2021
Verma, J. K., \& Dondapati, R. S. (2017). Techno-economic sizing analysis of solar PV system for domestic refrigerators. Energy Procedia. https://doi.org/10. 1016/j.egypro.2017.03.068

World Bank Group. (2017). Solar Resource and Photovoltaic Potential of Nepal. https://documents1.worldbank.org/curated/en/585921519658176633/ pdf/123705-ESMESMP150328-PUBLIC-NepalSolarMappingCountrySolarR esourceReportMarch.pdf.

World Data Atlas. (2018). Nepal - Total primary energy consumption. World Data Atlas. https://knoema.com/atlas/Nepal/Primary-energy-consumption. Accessed 5 Jan 2021.

\section{Publisher's Note}

Springer Nature remains neutral with regard to jurisdictional claims in published maps and institutional affiliations.

\section{Submit your manuscript to a SpringerOpen ${ }^{\circ}$ journal and benefit from:}

- Convenient online submission

- Rigorous peer review

- Open access: articles freely available online

- High visibility within the field

- Retaining the copyright to your article

Submit your next manuscript at $\boldsymbol{\nabla}$ springeropen.com 